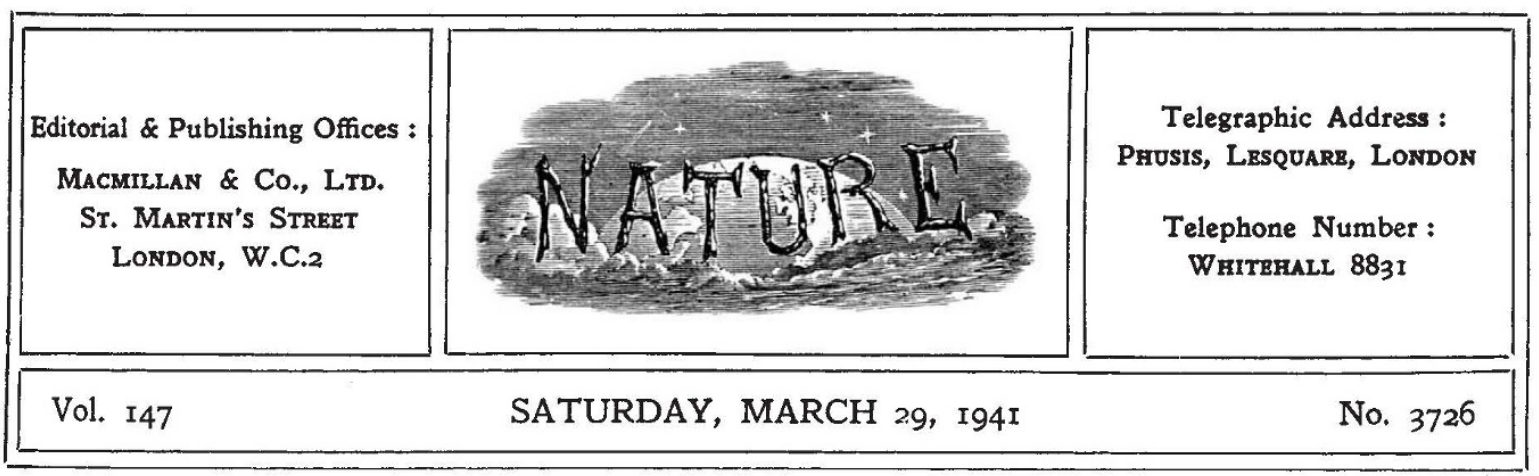

\title{
SCIENTIFIC UTILIZATION OF RESOURCES AND MAN-POWER
}

$\mathrm{T}$ HE Select Committee on National Expenditure has from the start taken a wide view of its functions, as an admirable series of reports testifies. Appointed to examine the current expenditure on the war services "and to report on what, if any, economies consistent with the execution of the policy decided by the Government may be effected therein", with its team of subcommittees, the Committee has constituted itself a body for keeping Government departments up to scratch in many matters which have only an indirect bearing on the war effort None of the reports yet issued by the Committee more fairly earns the thanks of the nation than the third and fourth reports, recently published, both of which discuss questions of man-power and production. That in its third report the Select Committee should have found it necessary to recapitulate at length the experience in regard to the relation between industrial output and hours of work, is the more disquieting in view of the seriousness of the man-power situation. The warning, it will be recalled, had already been given in a report issued by the Home Office early in the War, on hours of employment of women and young persons in factories, and in a later report prepared by the British Association for Labour Legislation.

The Sub-Committee on Supply Services of the National Committee now reports in fact that the lessons which the War of 1914-18 should have taught seem largely to have been ignored in respect of overtime and hours of work. Even if the demands on man-power had not been accentuated in the present struggle, failure to profit by past experience could not but handicap our efforts. A like failure to learn the lessons of the past is implied in the fourth report of the Select
Committee, on contracting. The co-ordinating subcommittee which submitted the report rightly observes that if maximum output is to be achieved the expenditure of national reserves-whether in man-power, in materials, or in capital equipment --must be at a minimum for each unit of output, and one indispensable method of bringing this about is to pay the closest attention to sound methods of contract procedure.

The prime necessity in a war economy is for the maximum and most efficient use of man-power and materials, and from the point of view of the elimination of waste this latest report is probably the most valuable of the eighteen that have so far appeared. Any contract price will contain four elements: the cost of materials, the cost of labour, overhead costs and profit, to which in main contractors' costs must often be added a fifth, payments to sub-contractors. The control of costs is, therefore, the simplest method by which to attain the maximum efficiency. The acute analysis of cost control and departmental organization, and the masterly survey of the conflict between urgency and carefulness in placing contracts, are examples of lucid thinking which should give the report an assured place in the literature of scientific management, carrying implications far beyond its immediate purpose.

The report indeed makes a distinct contribution to the scientific organization of our war effort, on the positive side as well as from the negative aspects of eliminating waste. With the details of this report only a few scientific workers, and chiefly those in administrative positions, are directly concerned. The report recommends a fixed price contract as the best type of contract. When a target is used with a maximum price 
contract, sufficient inducement should be given to the contractor to effect savings. Closer scrutiny should be given by departments to the costs allowed for labour on costed contracts, with the view of securing that it shall be employed in the most efficient manner, and severe comment on the time lost in doing all over again the costing and inspection work of reliable and experienced firms, and in doing it in several departments, leads to recommendations designed to avoid such waste and to stop duplication of costings by different State departments.

Great importance is attached to the fullest use being made of the capacity of small firms, and to the financing of such firms properly where necessary. The absence of co-ordination of departments is again the subject of severe strictures, although the difficulty of correcting inefficiency or economic defects is recognized. The importance of careful examination of departmental organizations to secure the maximum co-ordination in future planning, to ensure the allocation of labour to the best advantage, and of the effective tackling of the question of training and securing of potential labour, is stressed.

It is significant that the report should have to recommend that all constructional building, with the exception of fortifications and defence works, construction of aerodromes and works overseas, should in future be the responsibility of the Ministry of Works and Buildings. Similarly, the recommendation that the purchase of general stores, clothing and personal equipment should be the function of a separate new branch suggests that the work of allocating duties to the departments best fitted to receive them is not yet complete. The waste, inefficiency and lack of coordination brought to light, not for the first time, in this report should not be allowed to persist. It would indeed be deplorable if there were any delay in implementing the findings of this valuable and suggestive report.

As has already been indicated, the third and fourth reports have some ground in common. Looking at the matter from the point of view of economy, the fourth report points out that to meet the demand for speed by heavy overtime is not only costly, but also, as has been shown on many occasions, after a short period of application, causes a high sickness rate and other losses of effort symptomatic of industrial fatigue, and will finally result in an actual decrease in output. The third report deals with this question at greater length, three of its sections dealing with overtime, dilution and training of labour, and with the effect of overtime on costs.

Before the increased drive for production began in May last, the Sub-Committee on Supply Services was perturbed at the amount of overtime which was being worked. Excessive overtime was found to be bad for production, while if a certain amount of overtime was not worked, men left their factories for others where they could earn more by working overtime These symptoms were intensified as a result of the two months of extreme effort following the Government's appeal after the invasion of Holland and Belgium. Absenteeism became much more common and men arrived late for their work. Sunday labour led to men taking a day off in the middle of the week, when, of course, they only lost an ordinary day's pay. When at the end of July, in the Royal Ordnance factories, where absenteeism had risen to 15 per cent, it was decided to discontinue Sunday labour wherever possible, and very often Saturday afternoon as well, time-keeping improved and production did not suffer, or even increased.

The Sub-Committee accordingly strongly recommends that hours of work should be reduced to those set out in the Ministry of Labour's July circular as soon as possible. It is also essential that any reduction should be generally applied, in order to prevent men moving from one factory to another in search of longer hours and more pay. Only so can adequate account be taken of the four general facts, established during 1914-18, but recapitulated here so firmly and clearly by the Sub-Committee : increased hours of work above an optimum which varies slightly with different industries do not increase output proportionately, and may even result in a decrease; when heavy overtime is worked for prolonged periods, the general health of workers is undermined; if overtime has been prolonged a reduction in hours will increase output, though there will be a time-lag corresponding to recuperation of energy. If general health is undermined, a reduction to optimum hours will fail to effect the required increase of output.

A major cause of industrial fatigue is eyestrain, and the report recommends full and urgent investigation of the interior lighting of factories and workshops. The requirements of the black-out make it essential that methods of lighting scientifically devised to protect the worker from eyestrain should be fully investigated. It is also 
recommended that the spotter' system of roofwatching to avoid loss of production during airraids should be linked up with the Observer Corps, and that the removal or wiring of glass in the roofs of workshops should be expedited.

The main obstacle to the abolition of excessive overtime is the shortage of labour, especially skilled labour. The remedy for this is dilution and training, and the Sub-Committee considers that there should be a continued drive to attain the maximum dilution of labour. Once more it is urged that the compulsory powers regarding the movement of labour should, if necessary, be fearlessly used. It is particularly desirable that more training should be done in the factories themselves, in addition to the training centres set up by the Ministry of Labour. Moreover, excessive increase in costs is attributed to abnormal overtime increasing costs out of all proportion to the increase in production. The Sub-Committee records its opinion that this situation, in view of experience during 1914-18, should never have been allowed to rise. It accordingly recommends that more attention should be given by the costings department to labour costs, and action taken when they appear to be too high.

The regularity with which examples of failure to profit by past experience occur in these reports is one of their most disquieting features. No less disturbing in its implications is the admission that the Sub-Committee has so far been unable to see the actual costs of scarcely any articles which have been delivered since the War began, so that it has been unable to find out so far whether in its judgment the State is in fact paying too much for its war supplies. Such an admission is more than an indication of inefficient administration and inadequate checks on excessive costs. It amounts to thwarting the prime purpose of Select Committee to watch over expenditure on the war services.

The wide view of its functions which the Com. mittee has displayed in its reports, and the admirable balance of the reports, have won it already an established reputation, and its findings cannot be ignored without danger to the public weal. Even where, as in these latest reports, it makes numerous recommendations in matters of detail, such as constructive suggestions for preventing a break in production and unnecessary use of paper in sending out tenders and drawing up contracts, it is always clear that the wider issues are kept in mind, and that both policy and detail are being sifted by keen, analytical minds, untrammelled by tradition or departmentalism. The warnings conveyed so clearly and firmly in these latest reports are unmistakable. It is for scientific workers, with their fellow citizens, to see that there is no hiatus between this lucid thought and swift decisive action to eliminate the waste and handicaps which inefficient management, departmentalism or impatient but mistaken disregard of past experience, are placing on the development of our resources to their maximum capacity.

\section{AMERICAN VIEWS ON MODERN CULTURE}

Science, Philosophy and Religion

A Symposium. Pp. ix +443 . New York: Conference on Science, Philosophy and Religion, 1941.) 1.50 dollars.

THE papers contained in the present volume were prepared for a conference held in New York during September 9-11, 1940, the subject of the conference being "Science, Philosophy and Religion in their Relation to the Democratic Way of Life". Those who initiated the conference maintain that "civilization itself is threatened by the rise of totalitarian systems based on various anti-scientific, anti-philosophic, and anti-religious dogmas". They state-it is perhaps a hope rather than a conviction-that "our common background gives us a broad basis for a united, democratic
American way of life". "This way of life must be based ultimately on the religious principle of the Fatherhood of God and the worth and dignity of Man when regarded as a child of God". The conference after its meeting appointed a committee to meet representatives of the Press : this committee overcame the temptations of humility and pronounced the papers submitted to be "contributions of unusual merit to American learning". Further meetings are planned to take place in 1941 and 1942.

In the volume before us there are, including two introductory papers, twenty-four separate contributions. They form a somewhat closely printed and substantial volume. Naturally, they are of varying length-and value. Practically all their authors are associated with American universities, 